\title{
Bruise Development and Fruit Response of Pear (cv. 'Blanquilla') under Impact Conditions
}

\author{
Leonor Rodriguez Sinobas, ${ }^{a}$ Margarita Ruiz-Altisent ${ }^{b} \&$ \\ Jose Luis de la Plaza Perez ${ }^{a}$ \\ ${ }^{a}$ Instituto del Frio (CSIC), ${ }^{b}$ Department Mecanizacion Agraria, ETSI Agronomos, \\ Ciudad Universitaria, 28040 Madrid, Spain
}

(Received 1 June 1989; revised version received 20 November 1990; accepted 22 November 1990)

\begin{abstract}
Pear fruits cv. 'Blanquilla', at various ripening stages, were studied under impact conditions. A 50.6-g spherical steel indentator, with a radius of curvature of $0.94 \mathrm{~cm}$, was dropped on to the fruit from three heights: 4, 6 and $10 \mathrm{~cm}(0.0199,0.0299$ and $0.0499 \mathrm{~J})$. The variables measured were analyzed. All variables were observed to be related to the impact energy except impact duration, which was related to the fruit firmness. Bruising correlated with impact energy when considering different heights, but not with any specific variable when studying the impact phenomenon at individual heights; however, there was a clear correlation between impact bruising and firmness. Three bruise shapes were observed, corresponding to preclimacteric, climacteric and postclimacteric fruits; a theory for this response is offered. According to the results, the impact response in postclimacteric pear fruits (with firmness values of less than $25 \mathrm{~N}$, and a maturity index above 55) may be explained by the role played by the skin rather than by the pulp.
\end{abstract}

\section{INTRODUCTION}

The application of the theories of elasticity and viscoelasticity to the rheology of fruits and vegetables has been an important subject of study in recent years. Attention has been mainly directed to the response of these biological materials to applied loads and deflections which occur during the harvesting and handling process. In particular, considerable effort has been given to the development of criteria for predicting the 289

Journal of Food Engineering 0260-8774/91/\$03.50 - (C) 1991 Elsevier Science Publishers Ltd, England. Printed in Great Britain 
occurrence of bruising under applied stress, strain, or energy input (Holt \& Schoorl, 1977a; Chen et al., 1986).

Bruising in fruits occurs basically from the impact produced between fruits and against rigid surfaces, and by compression (Mohsenin, 1972; Dal Fabro et al., 1980). The susceptibility of fruits to bruising is determined by the size of the tissue softening and the discoloration that appears after loading, and is cultivar-dependent (Dedolph \& Austin, 1962; Mohsenin \& Goehlich, 1962; Hyde \& Ingle, 1968).

Factorial analysis of the studies performed on four Asian pear cultivars under impact and compressive conditions (Chen et al., 1986) showed the highest correlations among compression-bruise measurements and among measurements of applied compression and impacts. Both the depth and the width of bruise were not related in any particular way to the variables given or to any linear combination of them.

Topping and Luton (1986) observed in three apple cultivars an increase in the bruise diameter and volume with impact energy; this was cultivar dependent. Garcia et al. (1988) observed a close correlation between the development of the bruise and the impact variables within ripening stages in several apple and pear cultivars.

Holt and Schoorl $(1977 a)$ observed in 'Granny Smith' apples a close correlation between the absorbed energy and the bruise volume under mechanical impact. However, no correlation between the bruise volume and fruit firmness was found. They also observed a diminution of bruise size with storage (Holt \& Schoorl, 1977b).

The development of fractures has been reported in apples (Jarimopas, 1984; Garcia et al., 1988) and pears (Garcia et al., 1988) when exposed to impact loads. These fractures corresponded to the site where the maximum normal stress was produced and were characterized by the development of a brown color.

The objectives of this study were (1) to study the development of the bruise in 'Blanquilla' pear during ripening under three different impact loads, and (2) to determine the relationship between the mechanical and physiological variables measured and ripening.

\section{MATERIALS AND METHODS}

Fruits of 'Blanquilla' pear were transported from Alpicat (Lerida, Spain) to the postharvest laboratory of the Instituto del Frio by air-conditioned truck on the day of harvest. Fruits were classified for uniformity of color, size, shape, and freedom from mechanical injuries and decay. They were 
stored in a controlled temperature room at $1 \pm 0.5^{\circ} \mathrm{C}$ and $85 \%$ relative humidity for 3 months. Each week, 75 fruits were assessed; 60 of these were held at $18 \pm 0.5^{\circ} \mathrm{C}$ and $85 \%$ relative humidity for a week to accelerate ripening, and were subjected to impact testing.

The impact system was designed by Chen et al. (1985), and included a spherical steel indentator of $50 \cdot 6 \mathrm{~g}$ weight, with a radius curvature of $0.94 \mathrm{~cm}$ (Fig. 1). The device recorded the deceleration of the load when the indentator reached the fruit. The deceleration was calculated from the data given by an accelerometer connected to the end of the indentator, which was dropped from different heights. The acceleration was mathematically integrated, and a computer program determined the mechanical variables: impact energy, calculated absorbed energy, impact duration, permanent deformation, maximum deformation, and maximum impact force.

The impact energies were defined as the potential energy at the height from which the indentator was dropped $(4,6$ and $10 \mathrm{~cm})$, and were $0.0199,0.0299$ and $0.0499 \mathrm{~J}$, respectively.

Black ink was applied to the indentator surface to mark the area of contact. The bruise was cut in half with a sharp knife (perpendicular to the fruit surface) $2 \mathrm{~h}$ after the impact, and observed under a stereomicroscope, (Nikon model SMZ-2T, $\times 10-63$ ), which was equipped with a caliper and a camera. The bruise was defined by its width, depth and shape.

The remaining 15 fruits underwent the following procedure. Ten fruits were impacted on the cheek from three heights $(4,6$ and $10 \mathrm{~cm})$. Firmness was determined in each fruit by an Instron Food Testing Machine (model 1122 with a $9.7-\mathrm{mm}$ diameter plunger). The skin of the fruit was removed over an area of $1 \mathrm{~cm}^{2}$ before testing. Five fruits were used to determine the following characteristics of the sample: $(1)$ the soluble solids content $(\mathrm{E})$, determined by a digital refractometer (Atago dbx-30 with automatic temperature compensation); (2) the titratable acidity (A) from the juice samples, determined by titration, using $0 \cdot 1 \mathrm{~N} \mathrm{NaOH}$, to an end point of $\mathrm{pH} 8 \cdot 1$, following the method described by the International Federation of Fruits and Juices Makers, analysis no 3; and (3) the maturity index (E/A), expressed as the soluble solids content over the titratable acidity.

The respiration rate was monitored every day in a closed system. One fruit was selected each time, enclosed in a glass jar of 905-cc volume, and held at the same temperature and relative humidity as those fruits from the protocol cited above. The lid was kept tightly closed to ensure equilibrium, before withdrawing a gas sample with a $10-\mathrm{ml}$ syringe. The gas sample was analyzed by a gas chromatograph (Varian model 3700 ). 


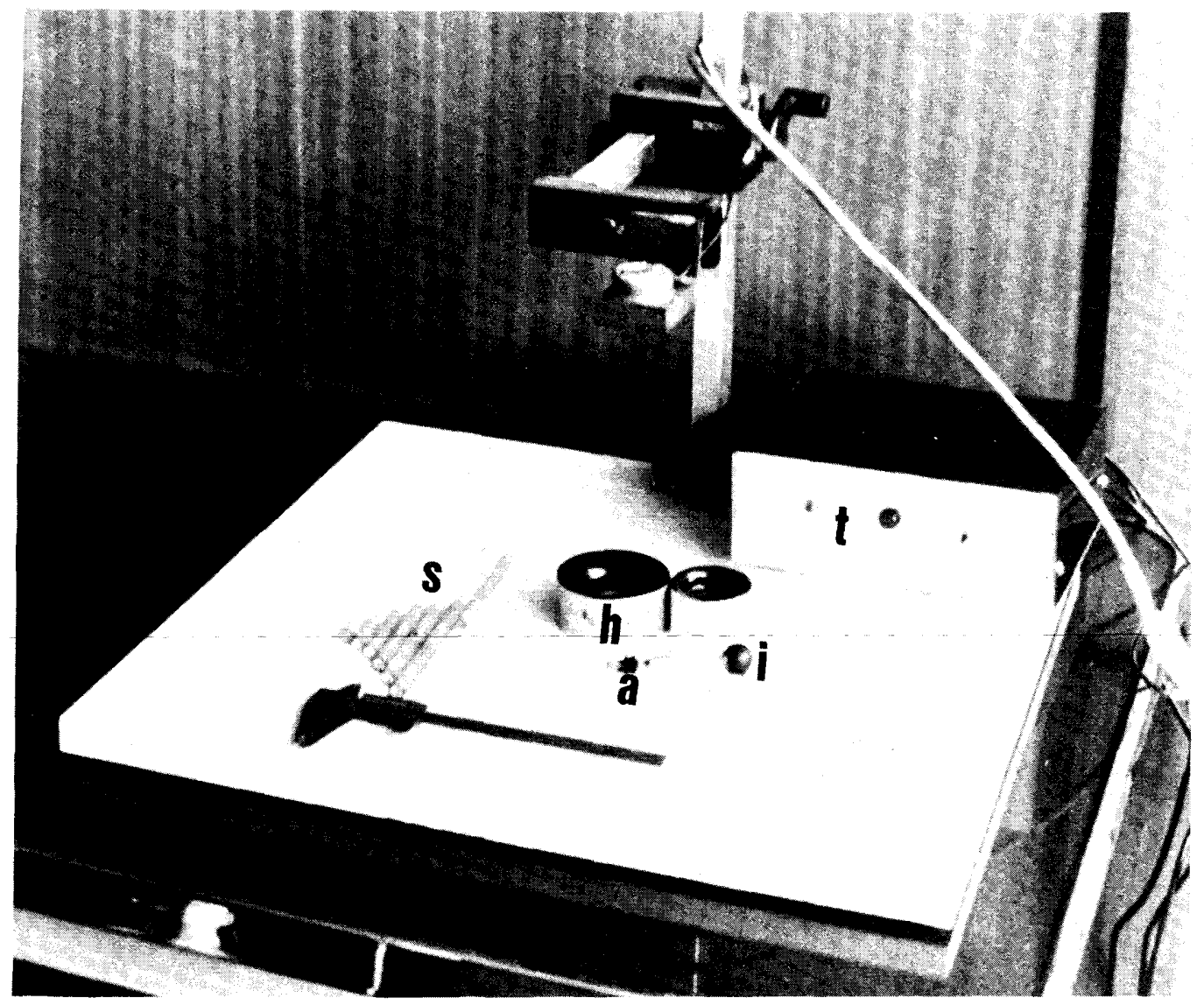

Fig. 1. Impact device used for 'Blanquilla' pears ( $a$, accelerometer; $h$, fruit holder; $i$, indentator; $s$, dropped heights standards; $t$, electronical transducer). 
On each of 4 days, 15 fruits were removed from the 60 stored at $18^{\circ} \mathrm{C}$. The total number of fruits studied under impact conditions was 290.

A Principal Component factor analysis of the results was made (Statistical Program BMDP 87). This analysis permits the impact phenomenon to be studied in a condensed dimensional space, using the quantified results to create new variables called factors. These factors were named according to the variables with the highest variance percentage in each factor. In addition, data were arranged in a scatter diagram. The groups formed around the factors showed different response to the impact conditions.

\section{RESULTS AND DISCUSSION}

When a range of different impact energies is taken into account, the variables determined (Table 1) are correlated with three main factors: impact energy (IE), impact duration (ID) to fruit firmness $(\mathrm{F})$ ratio, and physiological maturity.

All the mechanical variables except ID, which is related to $\mathrm{F}$ (Factor 3 ), correlated with IE (Factor 1) (Table 2). A linear regression analysis showed a regression coefficient $\left(R^{2}\right)$ of 0.98 between IE and the absorbed energy (AE). A and E/A were grouped in Factor 2. Bruise size, therefore, correlates with IE.

Figure 2 clearly shows three different groups of fruits divided according to the IE (Factor 1); these results confirm the importance of IE

TABLE 1

Variables Measured during the Impact Tests

\begin{tabular}{lcc}
\hline \multicolumn{1}{c}{ Variables } & SI units & Symbol \\
\hline Maximum impact force & $\mathrm{N}$ & $\mathrm{IF}$ \\
Maximum deformation & $\mathrm{mm}$ & $\mathrm{MD}$ \\
Permanent deformation & $\mathrm{mm}$ & $\mathrm{PD}$ \\
Impact energy input & $\mathrm{J}$ & $\mathrm{IE}$ \\
Calculated absorbed energy & $\mathrm{J}$ & $\mathrm{AE}$ \\
Impact duration & $\mathrm{ms}$ & $\mathrm{ID}$ \\
Firmness & $\mathrm{N}$ & $\mathrm{F}$ \\
Fruit acidity & $\mathrm{g}$ malic acid & $\mathrm{A}$ \\
& $100 \mathrm{~g}$ pulp & \\
Total soluble solids & ${ }^{\circ} \mathrm{Brix}$ & $\mathrm{E}$ \\
Maturity index & - & $\mathrm{E} / \mathrm{A}$ \\
Bruise depth & $\mathrm{mm}$ & $\mathrm{BD}$ \\
Bruise width & $\mathrm{mm}$ & $\mathrm{BW}$ \\
\hline
\end{tabular}


TABLE 2

Dependence Percentages in 'Blanquilla' Pear under Impact Conditions from 4, 6 and 10 $\mathrm{cm}$ of Height

\begin{tabular}{|c|c|c|c|c|}
\hline Variables & $\begin{array}{l}\text { Factor } 1 \\
\text { (IE) }\end{array}$ & $\begin{array}{c}\text { Factor } 2 \\
\text { (Maturity stage) }\end{array}$ & $\begin{array}{c}\text { Factor } 3 \\
(I D-F \\
\text { relationship) }\end{array}$ & $\begin{array}{c}\text { Explained } \\
\text { variance by } \\
\text { variable } \\
(\%)\end{array}$ \\
\hline IF & +82 & & +12 & 94 \\
\hline MD & +88 & & & 88 \\
\hline PD & +75 & & & 75 \\
\hline IE & +96 & & & 96 \\
\hline $\mathrm{AE}$ & +97 & & & 97 \\
\hline ID & & & -66 & 66 \\
\hline $\mathrm{F}$ & & & +66 & 66 \\
\hline $\mathrm{E}$ & & & & \\
\hline $\mathrm{BW}$ & +57 & & & 57 \\
\hline $\mathrm{BD}$ & +59 & & & 59 \\
\hline A & & -94 & & 94 \\
\hline $\mathrm{E} / \mathrm{A}$ & & +94 & & 94 \\
\hline $\begin{array}{l}\text { Explained variance by } \\
\text { factor }(\%)\end{array}$ & 56 & $19 \cdot 64$ & $15 \cdot 28$ & \\
\hline $\begin{array}{l}\text { Accumulated variance by } \\
\text { factor }(\%)\end{array}$ & 56 & $75 \cdot 67$ & $90 \cdot 95$ & \\
\hline
\end{tabular}

upon the fruit response under impact conditions, reported by previous authors (Hyde \& Ingle, 1968; Holt \& Schoorl, 1977a, b; Topping \& Luton, 1986; Chen et al., 1986; Garcia et al., 1988).

Figure 3 shows the fruit divided into two groups according to their physiological maturity (Factor 2). Group I contains fruit with $\mathrm{F}$ values above $25 \mathrm{~N}$, and Group II (senescent fruits) values below $25 \mathrm{~N}$. When a variance analysis was performed, both showed significant differences at the three IE values. A factor analysis for each group gave the same factors as those for all of the fruits combined.

If data are analyzed for individual heights in each group, four main factors are established (Table 3). Factor 1 includes the relationship between impact force (IF), maximum deformation (MD) and duration of impact (ID); this comprises several values of IE, and represents the IE in the study. Factor 2 illustrates physiological maturity. Factor 3 is constituted by the relationship between absorbed energy (AE) and permanent deformation (PD). Factor 4 comprises the bruise extent. In individual heights, bruising is not related to any specific variable either in Group I or in Group II; it correlates with F. 
FACTOR 2

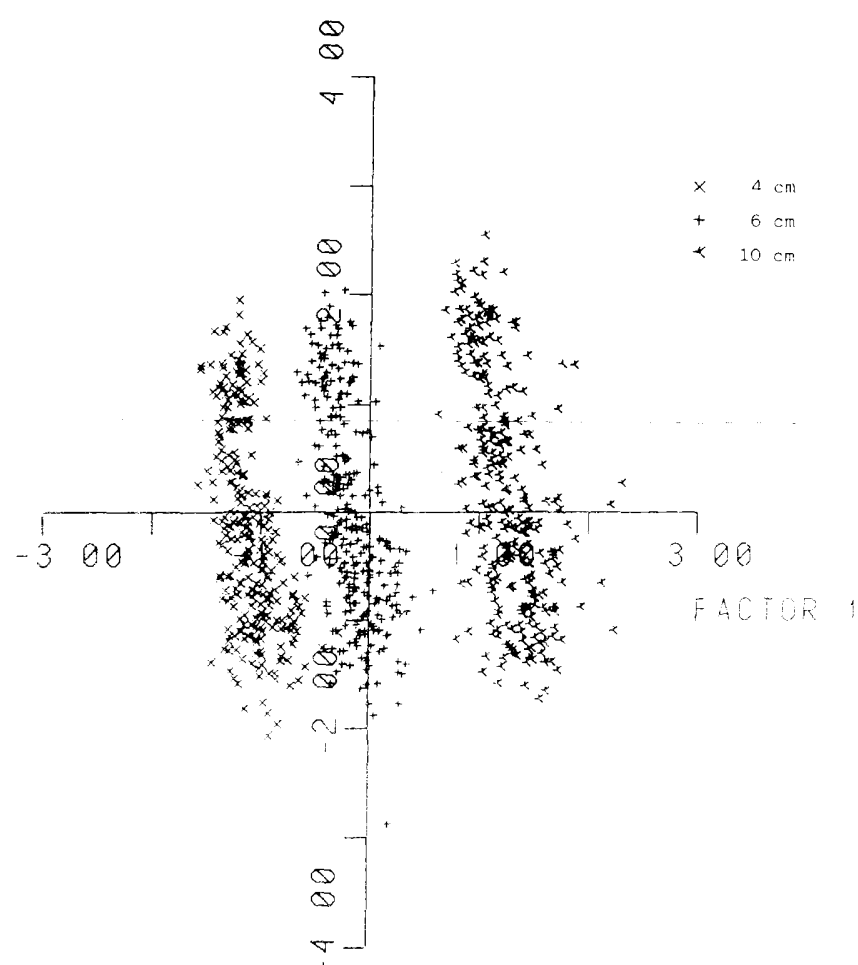

Fig. 2. Grouping of pear fruits cv. 'Blanquilla' into three groups according to IE (Factor 1) and ripeness stage (Factor 2) axes.
FACTOR 3

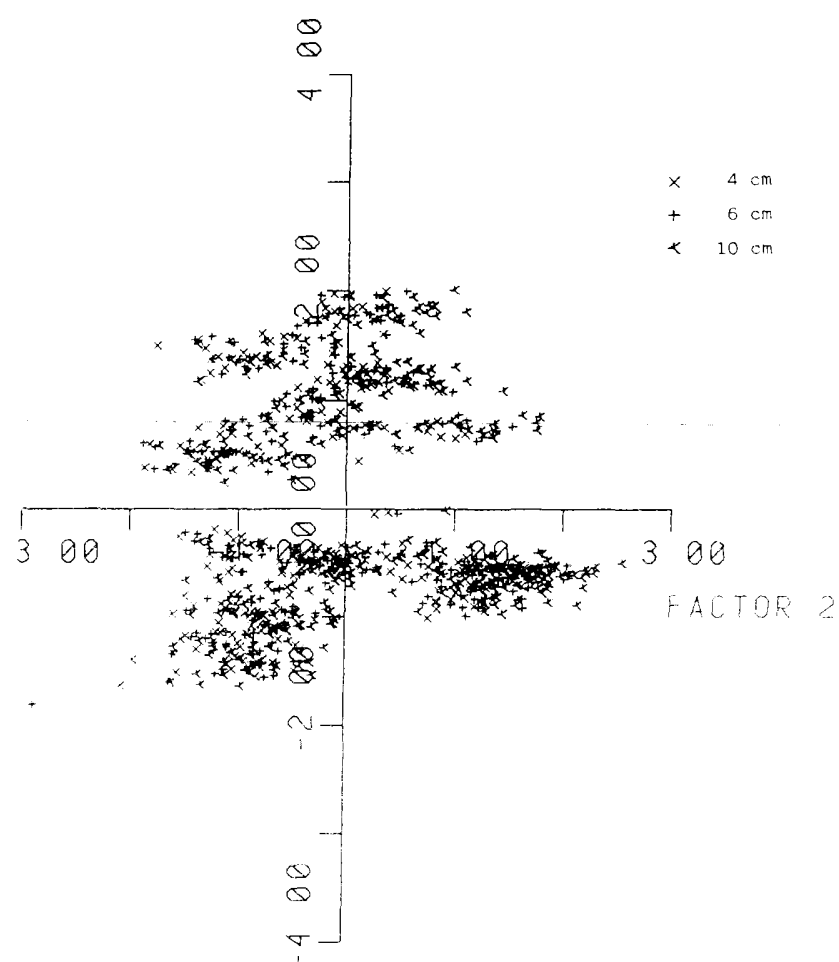

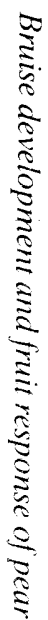

Fig. 3. Grouping of pear fruits cv. 'Blanquilla' into two groups according to the ripeness stage (Factor 2) and ID-F relationship (Factor 3) axes. 
TABLE 3

Dependence Percentages in 'Blanquilla' Pear under Impact Conditions from 4, 6 and $10 \mathrm{~cm}$ of Height

\begin{tabular}{|c|c|c|c|c|c|}
\hline Variables & $\begin{array}{c}\text { Factor } 1 \\
\text { (IF-MD-ID } \\
\text { relationship) }\end{array}$ & $\begin{array}{c}\text { Factor } 2 \\
\text { (Maturity } \\
\text { stage) }\end{array}$ & $\begin{array}{c}\text { Factor } 3 \\
\text { (AE-MD } \\
\text { relationship) }\end{array}$ & $\begin{array}{c}\text { Factor } 4 \\
\text { (Bruise) }\end{array}$ & $\begin{array}{c}\text { Explained } \\
\text { variance by } \\
\text { variable } \\
(\%)\end{array}$ \\
\hline IF & -91 & & & & 91 \\
\hline MD & +89 & & & & 89 \\
\hline PD & & & +73 & & 73 \\
\hline \multicolumn{6}{|l|}{ IE } \\
\hline $\mathrm{AE}$ & & & +71 & & 71 \\
\hline ID & +86 & & & & 86 \\
\hline$F$ & -17 & & -22 & -7 & 46 \\
\hline E & & +12 & & & 12 \\
\hline BW & +57 & & & +66 & 66 \\
\hline $\mathrm{BD}$ & +59 & & & +58 & 58 \\
\hline A & & -89 & & & 89 \\
\hline $\mathrm{E} / \mathrm{A}$ & & +95 & & & 95 \\
\hline $\begin{array}{l}\text { Explained variance by } \\
\text { factor }(\%)\end{array}$ & $29 \cdot 64$ & $20 \cdot 38$ & $18 \cdot 43$ & $15 \cdot 06$ & \\
\hline $\begin{array}{l}\text { Accumulated variance by } \\
\text { factor }(\%)\end{array}$ & $29 \cdot 64$ & $50 \cdot 02$ & $68 \cdot 45$ & $83 \cdot 51$ & \\
\hline
\end{tabular}

Table 4 shows a second order factor analysis performed on the factors obtained from the first analysis for each IE and each group. Bruising correlates with $\mathrm{AE}$ in Group I, in accordance with the results reported by Holt and Schoorl (1977a) and Topping and Luton (1986), and with the physiological maturity in Group II (senescent fruits). As a general trend, the latter group showed an increase in the reaction force during the advanced stages of ripening at 6 and $10 \mathrm{~cm}$ height.

The results from this group show that fruits with an E/A $>55$ have reaction force values greater than expected from their ripening stage. These results may be explained by the fact that in firm fruits (preclimacteric stage) epidermis and parenchyma do not show important differences in their morphological and physicochemical characteristics in their response to impact loads; therefore, it could be feasible to think that the response to impact loads is a combined effect of the epidermisparenchyma. However, as the ripening progresses, physiological changes in the pulp, such as softening, loss of turgor potential and cellular cohesion, and changes in the cuticular structure and composition in the 
TABLE 4

Factorial Analysis of Second Order in 'Blanquilla' Pears under Impact Conditions

\begin{tabular}{cccccccc}
\hline \multirow{2}{*}{$\begin{array}{c}\text { Drop } \\
\text { height }\end{array}$} & Variables & \multicolumn{3}{c}{ Group I } & \multicolumn{3}{c}{ Group II } \\
\cline { 3 - 6 } & & Factor 1 & Factor 2 & Factor 3 & Factor I & Factor 2 & Factor 3 \\
\hline \multirow{2}{*}{$4 \mathrm{~cm}$} & IF & -0.549 & & & +0.560 & & \\
& E/A & +0.420 & & & -0.569 & +0.425 & \\
& AE & +0.518 & & & +0.599 & +0.496 & \\
& Bruise & +0.504 & & & & +0.757 & \\
$6 \mathrm{~cm}$ & IF & & +0.874 & & +0.675 & +0.308 & \\
& E/A & & & +0.909 & & +0.792 & \\
& AE & +0.739 & +0.299 & -0.256 & +0.711 & & \\
& Bruise & +0.672 & +0.368 & -0.310 & & +0.492 & \\
$10 \mathrm{~cm}$ & IF & & +0.954 & & +0.784 & & \\
& E/A & -0.486 & & & -0.617 & +0.375 & +0.289 \\
& AE & +0.692 & & & & +0.892 & \\
& Bruise & +0.534 & & & & & +0.933 \\
\hline
\end{tabular}

epidermis (Pantastico, 1975), give rise to the speculation that the response to impact loads could be clearly different in the epidermis and the pulp. In senescent fruits, the epidermis could play a more important role than the parenchyma in the overall response to impact loads.

Figures 4 and 5 show the grouping of fruits from Groups I and II into two subgroups. The factors were IF-MD relationship (Factor 2 in Group I, and Factor 1 in Group II) versus physiological maturity (Factor 1 in Group I, and Factor 2 in Group II). According to the size and shape observed during ripening, three different types of bruising were determined (Fig. 6).

Conical bruises have been reported by Horsfield et al. (1972), Miles and Rehkugler (1973), and Garcia et al. (1988). These bruises were associated with preclimacteric fruits ( $F$ values between 40 and $60 \mathrm{~N}$ ), and present a discontinuity or a possible fracture (that is L-shaped with a sightly rounded angle). It divides two regions. Region 1 contains less damaged tissue, and has been previously reported by O'Brien et al. (1983); Region 2 is where the browning occurs.

Truncated bruises were observed in climacteric fruits $(\mathrm{F}$ values between 25 and $40 \mathrm{~N}$ ). These are characterized by a semi-elliptical boundary dividing Regions 1 and 2 . Region 2 shows less discoloration 


\section{FACTOR 2}

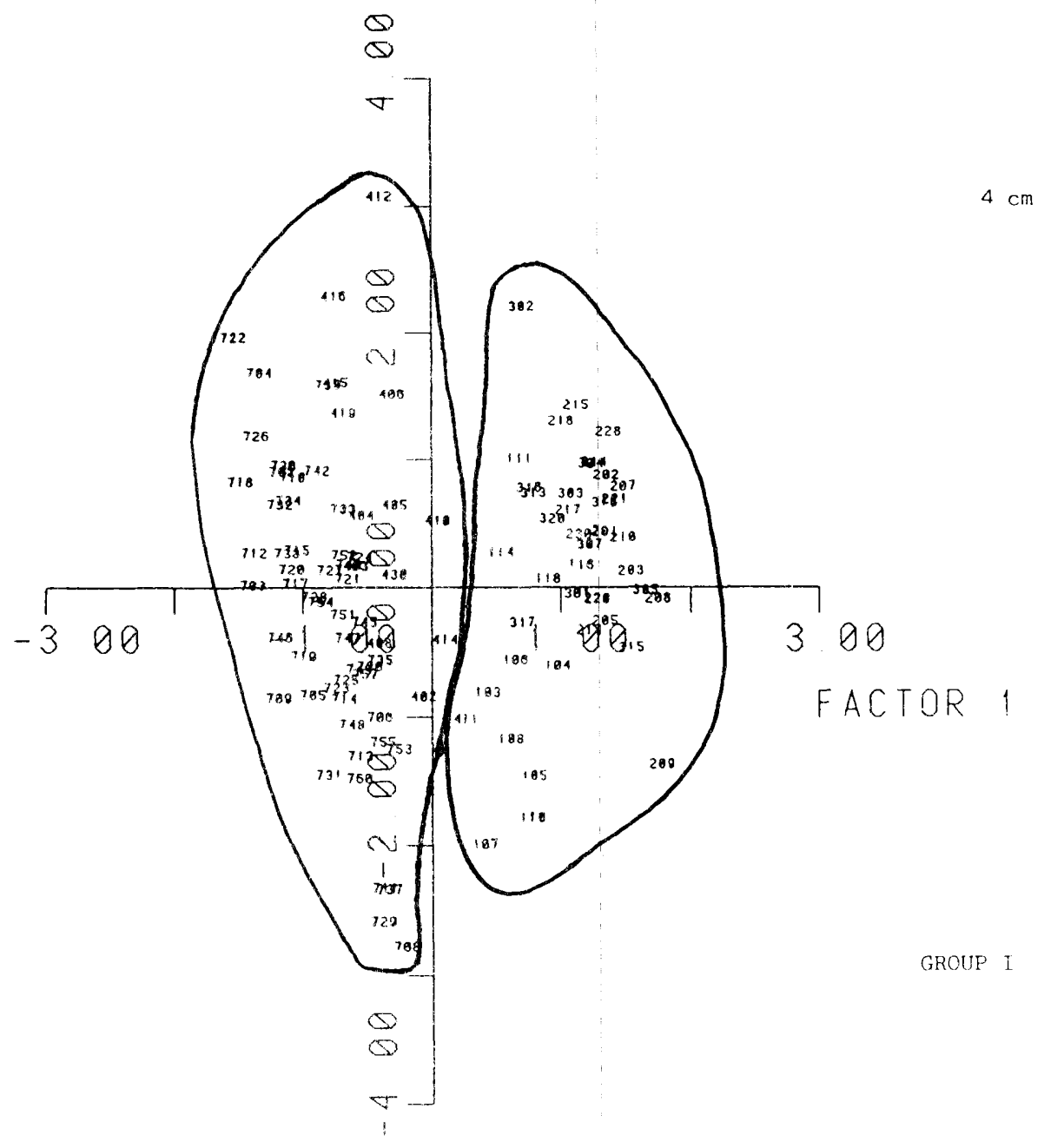

Fig. 4. Grouping of pear fruits cv. 'Blanquilla' belonging to Group I according to fruit physiological ripeness (Factor 1) and IF-MD relationship (Factor 2) axes.

than in the conical bruises; this is probably due to the solubilization process of the enzyme involved in the browning reaction. There is also a Region 3, which is translucent.

Trapezoidal or rectangular bruises are associated with postclimacteric fruits. The discontinuity is hardly visible. Region 2 is less colored; and Region 3 is larger and frequently difficult to differentiate from Region 2. 


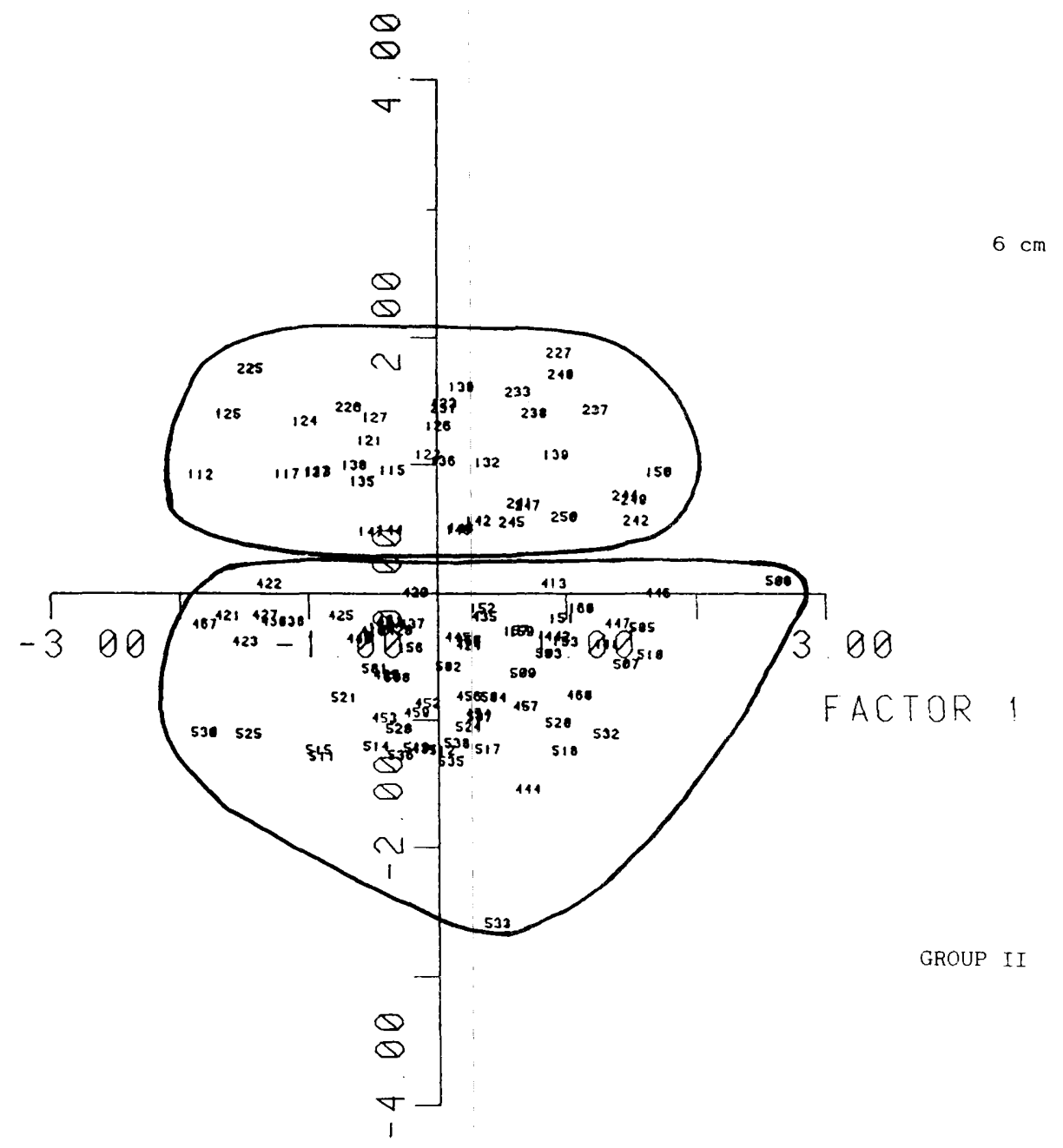

Fig. 5. Grouping of pear fruits cv. 'Blanquilla' belonging to Group II according to the IF-MD relationship (Factor 1) and fruit physiological ripeness (Factor 2) axes.

Changes in bruising types are gradual during ripening. The fruit changes its mechanical behavior during ripening. During the first stages of ripening the fruit shows organized tissue, firm and consistent, built up by turgid cells and rigid cellular walls and the presence of the middle lamella; it is considered to have an elastic behavior (Mohsenin, 1972). Under impact conditions, the stresses overcome the cell wall strength, 


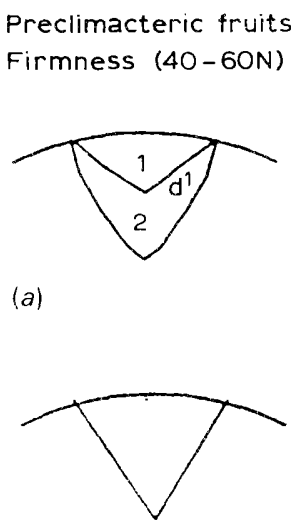

(b)

Conical

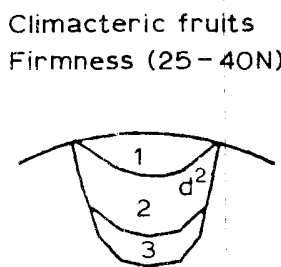

Postclimacteric fruits

Firmness $(\mathrm{O}-25 \mathrm{~N})$

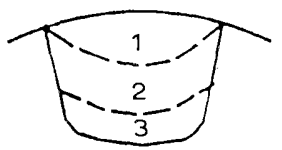

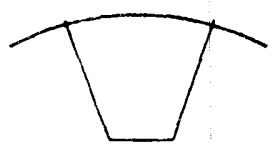

Truncated

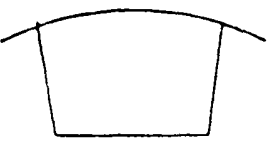

Rectangular

Fig. 6. Type of bruises produced by impact loads on 'Blanquilla' pears at different ripeness stages; (a) observed shapes of bruise; (b) associated geometrical shapes of bruise.

and when this break occurs, enzymes are released to cause the browning which characterizes the bruise.

In ripe fruits, the lateral stresses may become the more important under impact loads, and they would favor the development of bruises with truncated shape. In these bruises, the discontinuity would appear in the area where the stress is maximum, and it would produce the brown discoloration. The translucent zone may be formed by the sliding of cells caused by the splitting of the medium lamella. Since ripe fruits undergo softening, stresses can easily break the weak resistance of the middle lamella and split the cells.

In senescent or postclimacteric fruits, the tissue has lost its cohesion and firmness. Cell walls present a strong fibrillar degradation followed by the absence of middle lamellae. It is feasible that this condition will enhance a plastic response under applied loads. In these cases, the differentiation processes occurring in the epidermis and parenchyma make the epidermis (which undergoes a cellular lignification process and cuticular changes) behave as a very important barrier more resistant to applied loads.

Since the bruises found in postclimacteric fruits showed trapezoidal and rectangular shapes with a translucent texture, it is possible that in postclimacteric fruits lateral stresses predominate, and could facilitate the displacement of cells held in a non-cohesion network in different directions. 
Further studies are needed to examine in more detail how changes in the physiological characteristics of pulp and epidermis during ripening may affect the physical properties of the fruit under impact loads.

\section{REFERENCES}

Chen, P., Tang, S. \& Zong, S. (1985). Instrument for testing the response of fruits to impact. ASAE Paper no. 85-3537, Chicago, IL, 17-20 June.

Chen, P., Ruiz, M., Lu, F. \& Kader, A. A. (1986). Study of impact compression damage on Asian pears. ASAE Paper no. 86-3025, 30 (4), 1193-7.

Dal Fabro, J. M., Murase, H. \& Segerling, L. J. (1980). Strain failure of apple, pear and potato tissue. ASAE Paper no. 80-3048, San Antonio, TX, 15-18 June.

Dedolph, R. R. \& Austin, M. E. (1962). The evaluation of impact bruises on apple fruit. Proc. Amer. Soc. Hort. Sci., 80, 125-9.

Garcia, C., Ruiz, M. \& Chen, P. (1988). Impact parameters related to bruising in selected fruit. ASAE Paper no. 88-6027, Rapid City, SD, 26-29 June.

Holt, J. E. \& Schoorl, D. (1977a). Bruising and energy dissipation in apples. $J$. Text. Studies, 7, 421-32.

Holt, J. E. \& Schoorl, D. (1977b). The effects of storage time and temperature on the bruising of Jonathan, Delicious and Granny Smith apples. J. Text. Studies, 6 (4), 409-16.

Horsfield, B. D., Fridley, R. B. \& Claypool, L. L. (1972). Application of elasticity to the design of fruit harvesting and handling equipment for minimum bruising. Trans. ASAE no. 15-746, 15 (4), 746-53.

Hyde, J. F. \& Ingle, M. (1968). Size of apple bruises as affected by cultivar, maturity and time in storage. Proc. Amer. Soc. Hort. Sci., 92, 733-8.

Jarimopas, B. (1984). Failure of apples under dynamic loading. Research thesis, Faculty of Agricultural Engineering, Institute of Technology, Haif, Israel.

Miles, J. A. \& Rehkugler, G. E. (1973). A failure criterion for apple flesh. Trans. $A S A E, 16(6), 1148-53$.

Mohsenin, N. N. (1972). Mechanical properties of fruits and vegetables, review of a decade of research. Application and future needs. Trans. AAE, 15, 1064.

Mohsenin, N. N. \& Goehlich, H. (1962). Techniques for the determination of mechanical properties of fruits and vegetables as related to design and development of harvesting and processing machinery. J. Agric. Eng. Res., 7, 300.

O'Brien, M., Singh, R. P. \& Garret, R. E. (1983). The effect of bruising on dried fruit quality. Trans. ASAE Paper no. 83-6010, Chicago, IL, 13-16 December.

Pantastico, Er. B. (ed.) (1975). Postharvest Physiology, Handling and Utilization of Tropical and Subtropical Fruits and Vegetables, Avi Publishing Co., Westport, CT, 1975.

Topping, A. J. \& Luton, M. J. (1986). Cultivar differences in the bruising of English apples. J. Hort. Sci., 61 (1), 9-13. 